\title{
Social Capital as Knowledge Absorptive Capacity AND FIRM INNOVATION
}

\author{
Dr. Ploychompoo Kittikunchotiwut ${ }^{* 1}$ \\ ${ }^{1}$ Mahasarakham Business School, Mahasarakham University, Thailand, \\ Ploychompoo.k@acc.msu.ac.th, 66804657878
}

\begin{abstract}
The objective of the study is to investigate relationships amongst social capital, potential absorptive capacity, realized absorptive capacity, and firm innovation. The data were collected by using a questionnaire from 89 leather product exporting firms from leather products businesses in Thailand. The hypothesized relationships among variables are examined by using ordinary least square (OLS) regression analysis. The results indicate that social capital have are significant positive impact on potential absorptive capacity and realized absorptive capacity. Potential absorptive capacity and realized absorptive capacity have are significant positive impact on firm innovation. This study might be useful to scholars and those who share an interest in the subject. Moreover, theoretical and managerial contributions, conclusion, and suggestions for future research are also interesting to be discussed.
\end{abstract}

\section{Key Words}

Social Capital, Potential Absorptive Capacity, Realized Absorptive Capacity, Firm Innovation

\section{JEL Classification}

A13, D21, 031

DOI: https://doi.org/10.14311/bit.2018.01.02

Editorial information: journal Business \& IT, ISSN 2570-7434, CreativeCommons license (c) (i) published by CTU in Prague, 2018, http://bit.fsv.cvut.cz/

\section{Introduction}

Technology-intensive industries face a hugely competitive market. The landscape in which many firms operate sees daily increasing customer demands and a complex, rapidly growing knowledge base. This knowledge base is growing; becoming widely distributed across the globe. Within this landscape, the ideas of potential absorptive capacity and realized absorptive capacity are being realized as an untapped well of firm innovation (Daghfous, 2004; Prajogo and Ahmed, 2006). These are not the only factors, as firm innovation is influenced by a variety of factors both provisional and circumstantial (Roberts and Amit, 2003; Roberts, 2003). Take, as an example, the idea of learning activities. To increase the amount of firm idea generation, some organizations have seen an increase in finding information through the concept of relationship learning. Relationship learning can be defined as sharing a firm's information regarding technological changes in order to lead to an increase in global competition 
(Cohen and Levinthal, 1990). This ability to absorb information has been referred to as absorptive capacity, and is found to be an important factor for organizational learning and innovation (Nahapiet and Ghoshal, 1998).

Scholars have concluded that Cohen and Levinthal were the original finders of the true scope of absorptive capacity. This means that they were the first to create a true and lasting definition of the term as well as the first to see the groundwork surrounding its existence, especially when looking at the effects it would have in the business environment. It is important to include their definition of absorptive capacity, which is as follows: "the ability of a firm to recognize the value of new external information, assimilate it and apply it to commercial ends" (Cohen and Levinthal, 1990). Zahra and George (2002) have, in order to attain further knowledge of this process, attempted to add to the definition in recent years. They have suggested the idea that absorptive capacity is not stagnant, but is in fact dynamic as a capability. They have also pointed towards the subsistence of two specific areas of absorptive capacity: potential and realized. Potential absorptive capacity refers to the acquisition of information as well as how it is utilized in the company, whereas realized absorptive capacity refers to the changing and exploitation of information for a company's own gains. Previous studies have conjectured that both social networking and knowledge absorptive capacity can be vital conduits which allow organizations to attain information. Firms can use such networks to pick up useful and important knowledge and ideas which have the ability to help them to increase their internal abilities to learn and innovate (Ahuja, 2002, Inkpen and Tsang, 2005). However, there has yet to be research that explores if there is an interconnection between social capital and knowledge absorptive capacity. This is a significant lack that this study aims to put an end to.

Thus, this study aims to address the above limitation by examining how the composition of a social capital affects the knowledge absorptive capacity and firm innovation. In addition, this investigation contributes to the literature and practice in several ways. The main purpose of this paper is to investigate the relationships amongst social capital, potential absorptive capacity, realized absorptive capacity, and firm innovation. The key research question is how social capital, potential absorptive capacity, realized absorptive capacity, and firm innovation. Moreover, to highlight this relationship, three specific research questions are established as follows: (1) How social capital is related to potential absorptive capacity and realized absorptive capacity; (2) How potential absorptive capacity is related to firm innovation; (3) How realized absorptive capacity is related to firm innovation.

\section{Literature review and hypothesis development}

\section{Social capital, potential absorptive capacity and realized absorptive capacity}

Social capital has been gaining importance lately. Social capital is essentially how relationships allow a community to thrive (Flap,1991; Flap,1999). Social capital is one of those few resources that is conceivably (Marshall, 1920) through the actions of the organization with the purpose of increasing the rate of successfulness for definitive behaviors (Lin, 2001). According to Nahapiet and Ghoshal (1998) social capital is composed of two main elements: "1) it is embedded within the social network; and 2 ) it is a resource that can be obtained and used by the actor" One of the instincts of social capital theory is that positive interactions engender positive relationships between groups and individuals, and that those positive interactions can be used to meet targets (Adler and Kwon, 2002). Consequently, social capital's value is found in its ability to connect organizations with resources that they would not other have. These resources include, but are not limited to, "intellectual, financial, and cultural resources" (Bourdieu, 1986).

Social capital has grown in the area of entrepreneurship as well. It is seen as an addition, or complement, to previously existing theories that also focus on an individual's particular virtues. These 
theories recognize that entrepreneurs are influenced by the zeitgeist of the current culture which allows social behavior to flourish, but also places constraints on that behavior (Aldrich and Zimmer, 1986). The rise in theorizing in network-based concepts can be seen in the increase of studies and articles looking at networking and entrepreneurship. The popularity of this research topic has lead to deep analysis of the part that social capital plays in building and maintaining new organizations (De Carolis et al., 2009), how well those organizations are able to perform (Lechner et al., 2010), the inventiveness of those organizations within their own regions (Whittington et al., 2009) and how these organizations are changing and growing in their respective fields (Péron-Pinvidic et al.,2009).

Social capital allows for a variety of actions related to the development of information. There is a created and theorized landscape, which has been developed in order to show how social capital aids in the creativity of organizations by dividing social capital into three different elements: "structural, relational, and cognitive." The first element involves the availability and quality of the networks that the organization has access to. That is, where the organization stands in the social network; who can be contacted by the organization and what kind of knowledge can be gleaned from their contacts (Burt, 192). The second dimension, that is relational social capital, is involved with the quality, rather than the quantity, of the relationships that the organization, relationships influence behavior, and the quality of an organization's relationships can determine its ability to thrive and cooperate in its community (Fukuyama, 1995). The final dimension, cognitive social capital, looks at knowledge as a resource in an organization. An organization must have the ability to gain knowledge, share knowledge, and display its knowledge for employees to be able to learn and work with new information (Nahapiet and Ghoshal, 1998). There is also a proposed "structural dimension" involved in social capital; trust (Tsai and Ghoshal, 1998). Trust is paramount to sharing of knowledge and other resources; a company will not share information if it believes that those whom it shares with will use the knowledge against them. However, as seen from previous arguments, innovation is much more difficult without a sharing of knowledge. "Knowledge is the most powerful engine of production" (Marshall, 1920). In order to seek out new knowledge and use that knowledge in a way that is beneficial to the organization, the organization must be able to grow and nurture its absorptive capacity. In this case, absorptive capacity refers to the capacity to appraise, comprehend, and implement information taken from sources outside of the organization. These sources include "suppliers, customers, competitors, and alliance partners" (Cohen and Levinthal, 1990). Of course, those aforementioned abilities are only helpful if the organization is then able to create something innovative from this prior knowledge. Therefore, absorptive capacity is assumed to be progressive and changing when applied to information innovation and application; especially when used to increase an organization's capacity to grow and preserve an advantage in the competitive market (Zahra and George, 2002).

A recent study on absorptive capacity; adopting the schema which was created by Zahra and George (2002) allows the concept of absorptive capacity to be categorized into the categories of potential and realized. "Potential absorptive capacity makes the firm receptive to acquiring and assimilating external knowledge"(Zahra and George, 2002). There are two main components of potential absorptive capacity: cognizance achievement and cognizance utilization. Cognizance achievement can be defined as an organization's capacity to classify and gain information from outside sources which are very important for it to function (Zahra and George, 2002). Then cognizance utilization can be defined as the company's patterns and techniques which enable the company to have the ability to scrutinize, understand, and distinguish from outside entities the important data from the unimportant data.

On the other hand, realized absorptive capacity is a responsibility of a particular organization to change, innovate, and utilize the capabilities of the organization (Zahra and George, 2002).Transformation relates to the aptitude to evolve in order to clarify the daily functioning's that allow for the mixing between information that a company has already acquired and newfound information. In this sense, exploitation can refer to the daily functions that enable an organization to change and elongate abilities 
which are already in place (or to create and assimilate new abilities). The organizations do this by including information that has been newly added and adapted to fit the company's own functioning (Zahra and George, 2002).

Potential and realized absorptive capacity make up the building blocks of the knowledge chain; awareness and responsiveness, much like Welsch's et al., (2001). This chain of information draws attention to the necessity of not only possessing information, but having the ability and desire to use that information as needed (Welsch, Liao, and Stoica, 2001). It is important to look at this chain because prior studies typically only took certain parts of knowledge acquisition into account (Stock, Greis, and Fischer, 2001; Tsai, 2006). Due to this, the knowledge gained is not used to its full potential in regards to creating value and augmenting the current processes.

\section{Firm Innovation}

Organizational innovation must come from knowledge before being able to acquire knowledge. That knowledge must be sought out, understood, and harmoniously incorporated into the organization in order to have modern innovation. Based on (Cohen and Levinthal, 1990) existing works on absorptive capability, an organization's pre-existing knowledge is the foundation that must be used in order to find new knowledge. Without this foundation, new knowledge cannot be sought out in the first place. This knowledge directly translates to absorptive capability. Thus, an organization which has absorptive capability at powerful amounts have the capacity to gain new information from a broader variety of networks. They will be able to increase the novelty and modernity of their designs and have a better chance of incorporating these innovations in their firms (C. Lee, K. Lee, J.M. Pennings, 2001).

The argument that knowledge must come from previous knowledge agrees with the studies already completed ideas based on resources and pertaining to organizations and the techniques used that allow that organization to learn (Zollo and Winter, 2002). Organizational inventiveness and an entrepreneurial attitude is essential in order for not just the organization, but the entire economy, to prosper and grow (Schumpeter, 1934). Moreover, long-term gains have been investigated thoroughly and have been correlated with the capability to organizational innovation (Szymanski et al., 2007). One of the prominent causations of absorptive capacity has also been found to have been long-term gains (Zahra and George, 2002).

The concept of innovativeness has been defined and redefined again and again. Liao (2007) divided innovativeness into radical and incremental innovation. Radical innovation concerns taking in new information and creating something completely contemporary; whether that contemporary creation be a product or a service is irrelevant. Incremental innovation, on the other hand, can be thought of as a redesign of existing information and techniques in order to augment products or services (Henderson and Clark, 1990). Thus, in order to have an increased performance and in order to render the organization's competition outmoded, it is necessary to have continual innovation (regardless of the innovations being termed radical or incremental). The ability of an organization to utilize new information is, consequently, the foremost indicant for success in the competitive market. It should also be noted that the type of differing information, and domains from which that information came from, in an organization also indicate possible potential to outmatch the competition.

The evidence has provided that the more absorptive capacity leads to a larger capability to use ingrained information as well as learn new information from foreign systems and, consequently, it also leads to improved results as far as innovation and creativity are concerned (Cohen and Levinthal, 1990). Despite this, there are those who argue that information from outside of the organization itself is the key to creativity and innovative design. However, whether an organization can learn and use this information is based on that organization's past observations and current effectiveness. Either way, it is the social network of an organization which lets the organization find knowledge by sifting through 
outside information (Nelson, Fleming, Sorenson, 2004). Having a large network saves resources such as time and money for the organization to expend later on future research and development. An organization's internal abilities to evolve allows it to classify, learn, and utilize the new information that it acquires from foreign sources (Powell and Koput, 1996). Therefore, when an organization incorporates higher amounts of absorptive capability, insight and knowledge gained in the networks increases too. Specifically, an organization's absorptive capability and information from foreign sources complement each other. In other words, when an organization is allowed access to a wide information base, the absorptive capability that the organization already possess will have a significant role on how much the organization can improve their creativity and modernity using the same resources as their counterparts using actions such as seeking knowledge, interpreting that knowledge, and using the information that they have found (Kogut and Zander, 1992). Innovation is the taking of old information and transforming it into new knowledge that the organization can use and possess to help them with future innovation of new knowledge that they acquire (Arora and Fabrizio, 2009). The quest for information becomes more expedient when an organization has the ability to better use their absorptive capacity. This leads to an increase of diversification in the performance and acquisition of technological knowledge (Laumann, 1978).

\section{The research framework of this study}

This study proposed four hypotheses, and showed the research framework in Fig. 1.The theoretical model which will be developed in the following. The model proposes the influence of social capital, potential absorptive capacity, realized absorptive capacity and firm innovation. Firm innovation as our ultimate dependent variable is about the commercialization of a firm's innovation efforts (Joshi et al., 2010), i.e., the innovation launch of new products or services. Organizational knowledge, which corresponds to the firm's collective rest on market and technological knowledge, forms the foundation for developing new products or services. Therefore, organizational knowledge contributes to firm innovation. As mentioned previously, firm innovation is about exchanging and combining knowledge. Thus, potential absorptive capacity and realized absorptive capacity play an important role for firm innovation. In the following section, the propositions will be derived from existing theory.

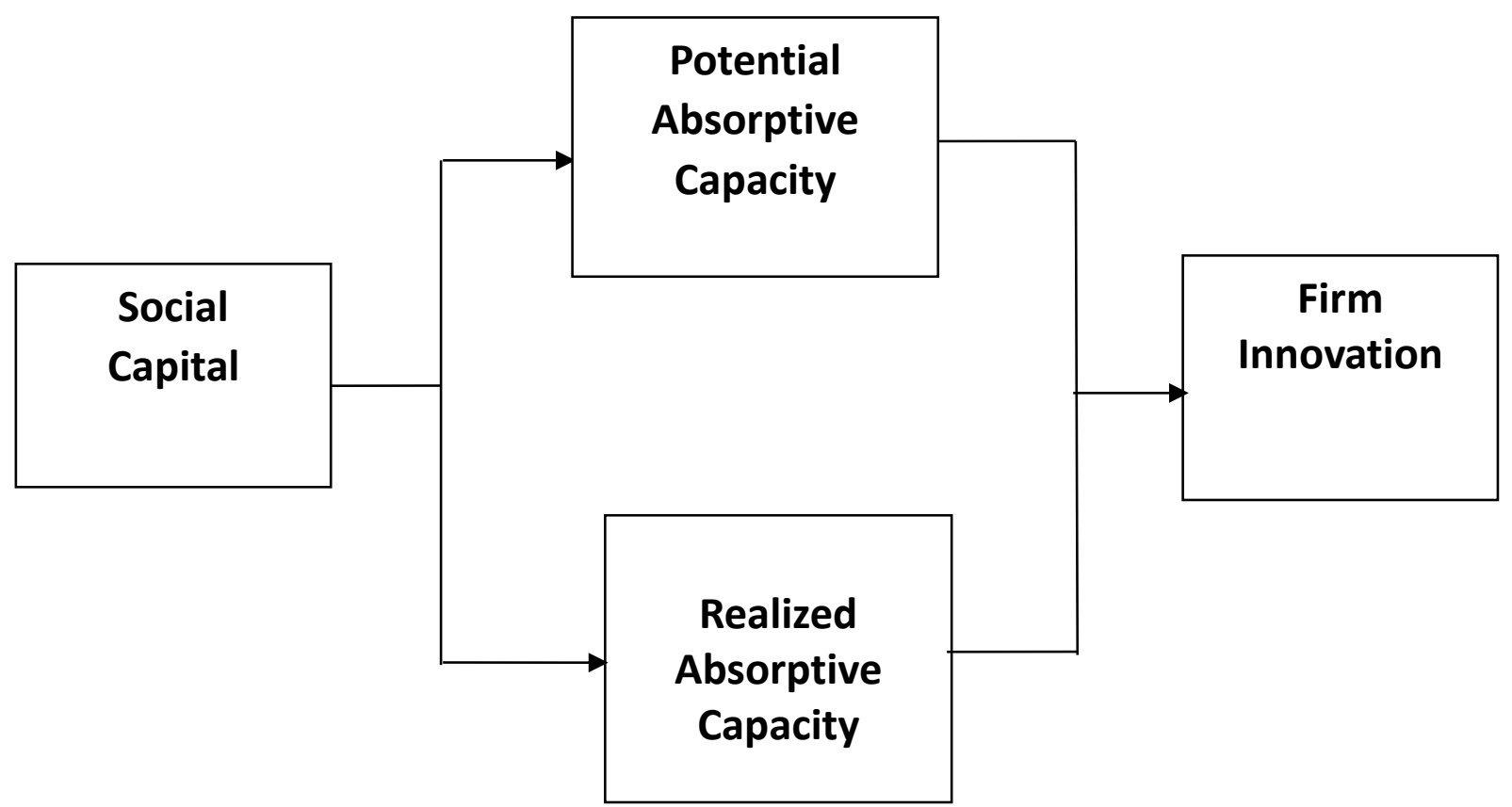

Figure 1: Research Framework. 


\section{Methodology and measurement}

\section{Data collection the sample}

This study investigates the relationship between social capital, potential absorptive capacity, realized absorptive capacity, and firm innovation. Therefore, this study selected exporting firms from leather products businesses in Thailand as the sample. The population was obtained from a list database of Thailand's exporter directory at the Department of Export Promotion, Ministry of Commerce of the Thai government as of April 20, 2017 (http://www.depthai.go.th). A mail survey procedure via questionnaire was used for data collection. The key participants in this study were executives or managers. With regard to the questionnaire mailing, 8 surveys were undeliverable because some firms were no longer in business or had moved to unknown locations. Deducting the undeliverable from the original 316 mailed, the valid mailing was 308 surveys, from which 92 responses were received. Of the surveys completed and returned, only 89 were usable. The effective response rate was approximately $28.89 \%$. According to Aaker, Kumar and Day (2001), the response rate for a mail survey, without an appropriate follow-up procedure, and greater than $20 \%$, is considered acceptable.

Furthermore, a non-response bias test was performed by comparing early and late responses. Characteristics of the firms comprise industry types, amount of capital funding, time in business, number of employees, and key informants who self-reported all constructs (Armstrong and Overton, 1977). As for non-response bias, t-test statistical tests were performed and; the results exhibited no significant differences. Therefore, a non-response bias is of no concern in this data.

\section{Measurements of the constructs}

The survey instrument is a multi-item measures. All the variables were measured using five-point Likert scales. The key informants were asked for the levels of agreement with statements of items ranging from 1 (strongly disagree) to 5 (strongly agree). The items were developed from existing scales of each variable for this study specifically.

\section{Social Capital}

The study focuses on the external dimension of social capital. The study includes a four-item scale based on the research of Maurer and Ebers (2006); Inkpen and Tsang (2005) to measure the relational side of external social capital.

\section{Potential Absorptive Capacity and Realized Absorptive Capacity}

We decided to use two measures of the firm's absorptive capacity. These measures were constructed using responses to questions regarding with the firm's use of different mechanism to acquire external knowledge and the firm's use of external agents as knowledge sources to develop innovations. Although we have labelled these variables potential absorptive capacity and realized absorptive capacity, the indicators constructed capture only two dimensions, one for each component: acquisition and exploitation. However, these indicators can be considered satisfactory to evaluate the relationships described at the beginning of this section.

\section{Firm Innovation}

To capture the varied aspects of firm innovation, this study built the construct for measuring product, process and overall assessment of organizational innovation on the basis of several criteria that were conceptualized and used in pervious empirical studies of innovation (Cordero, 1990; Utterback and Abernathy, 1975). 


\section{Control Variables}

The control variables were firm age and firm size. Size: The study estimates firm size using the natural logarithm of the number of employees, as in previous research (Cardinal, 2001). Age: Following Sorensen and Stuart (2000) the study also controls for firm age (2008 minus the year the company was founded).

\section{Methods}

In this study, factor analysis is used to study the construct validity of several constructs in the conceptual model that has been developed as scales. Factor analysis was used to assess the basis of a large number of items and to determine whether they could be reduced to a smaller set off actors. All factor loadings are higher than the rule-of-thumb 0.40 cut-off and are statistically significant (Nunnally and Berstein, 1994).

Moreover, Cronbach's alpha coefficient was used to evaluate the measurement of reliability. In the scale, Cronbach's alpha coefficients are higher than 0.70 (Nunnally and Berstein, 1994).Therefore, scales of all measures are shown to result in consistency. So, these measures are considered appropriate for further analysis because they show that validity and reliability that have be recognized in this study. The result shows factor loadings and the Cronbach's alpha coefficient for multiple item scales used this study in Table 1. Table 1 presents all variables that have factor loading scores as between $0.779-0.969$. Additionally, Cronbach's alpha for all variables are shown between $0.846-$ 0.877 . Therefore, all constructs of the validity and reliability of measurement can be applied for further analysis.

Table 1: Results of Measure Validation.

\begin{tabular}{|l|c|c|}
\hline \multicolumn{1}{|c|}{ Items } & $\begin{array}{c}\text { Factor } \\
\text { Loadings }\end{array}$ & $\begin{array}{c}\text { Cronbach's } \\
\text { Alpha }\end{array}$ \\
\hline Social Capital (SC) & $0.841-0.944$ & 0.877 \\
\hline Potential Absorptive Capacity (PA) & $0.779-0.968$ & 0.868 \\
\hline Realized Absorptive Capacity (RA) & $0.805-0.969$ & 0.846 \\
\hline Firm Innovation (FI) & $0.873-0.904$ & 0.850 \\
\hline
\end{tabular}

The ordinary least squares (OLS) regression analysis is used to test and examine the hypothesized relationships between dependent and independent variables of exporting firms from leather products businesses in Thailand. Then, the aforementioned variables play significant roles in explaining the research relationships. Because all dependent variable, independent variables, and the control variables in this study were neither nominal data nor categorical data, OLS is deemed an appropriate method for examining the hypothesized relationships (Aulakh, Kotabe and Teegen, 2000). With the interest of understanding the relationships in his study, the research model of these relationships is depicted as follows.

$$
\begin{aligned}
& \text { Equation 1: } \mathrm{PA}=\beta 01+\beta 1 \mathrm{SC}+\beta 2 \mathrm{FA}+\beta 3 \mathrm{FS}+\varepsilon \\
& \text { Equation 2: } \mathrm{RA}=\beta 02+\beta 4 \mathrm{SC}+\beta 5 \mathrm{FA}+\beta 6 \mathrm{FS}+\varepsilon \\
& \text { Equation 3: } \mathrm{FI}=\beta 03+\beta 7 \mathrm{PC}+\beta 8 \mathrm{FA}+\beta 9 \mathrm{FS}+\varepsilon \\
& \text { Equation 4: } \mathrm{FI}=\beta 04+\beta 10 \mathrm{RA}+\beta 11 \mathrm{FA}+\beta 12 \mathrm{FS}+\varepsilon
\end{aligned}
$$




\section{Results and Discussion}

Table 2 Means, Standard Deviations, and Factor Correlations with respect to the possible problems relating to multicollinearity among independent variables, variance inflation factors (VIFs) range from 1.09 to 2.99 which was below the cut-off value of 10 as recommended by Neter, William and Michael (1985), meaning the independent variables are not correlated with each other. Therefore, there are no substantial multicolinearity problems encountered in this study.

Table 2: Means, Standard Deviations, Factor Correlations.

\begin{tabular}{|c|c|c|c|c|c|c|}
\hline Variables & SC & PA & RA & FI & FA & FS \\
\hline Mean & 4.202 & 4.236 & 4.359 & 4.224 & 3.1347 & 2.764 \\
\hline S.D. & 0.709 & 0.674 & 0.772 & 0.670 & 1.119 & 1.331 \\
\hline SC & 1 & & & & & \\
\hline PA & $0.326^{* *}$ & 1 & & & & \\
\hline RA & $0.363^{* *}$ & $0.730^{* *}$ & 1 & & & \\
\hline FI & $0.309^{* *}$ & $0.837^{* *}$ & $0.633^{* *}$ & 1 & & \\
\hline FA & 0.137 & 0.003 & 0.009 & 0.095 & 1 & \\
\hline FS & 0.159 & 0.126 & 0.161 & 0.111 & $0.456 * *$ & 1 \\
\hline$* * * p<0.01, * * p<0.05, * p<0.10$ & & & & \\
\hline
\end{tabular}

Table 3 presents the results of OLS regression analysis of the relationship between social capital and potential absorptive capacity. The first one of relationship between social capital and potential absorptive capacity is significant $(\mathrm{H} 1 \mathrm{~b} 1=1.058, \mathrm{p}<0.01)$, thus, Hypothesis 1 is supported.

Table 3: Results of Regression Analysis.

\begin{tabular}{|l|c|}
\hline \multirow{2}{*}{$\begin{array}{l}\text { Independent } \\
\text { Variables }\end{array}$} & Dependent Variables \\
\cline { 2 - 2 } & Potential Absorptive Capacity \\
& $(\mathrm{PA})$ \\
\hline Constant & $-0.453^{* * *}$ \\
& $(0.105)$ \\
\hline Social Capital (SC) & $1.058^{* * *}$ \\
& $(0.025)$ \\
\hline Firm Age (FA) & 0.007 \\
& $(0.005)$ \\
\hline Firm Size (FS) & 0.000 \\
& $(0.005)$ \\
\hline Adjusted $\mathrm{R}^{2}$ & 0.954 \\
& \\
\hline
\end{tabular}

${ }^{* * *} p<0.01,{ }^{* *} p<0.05,{ }^{*} p<0.10,{ }^{a}$ Bata coefficients with standard errors in parenthesis 
Table 4: Results of Regression Analysis.

\begin{tabular}{|l|c|}
\hline \multirow{2}{*}{$\begin{array}{l}\text { Independent } \\
\text { Variables }\end{array}$} & Dependent Variables \\
\cline { 2 - 2 } & Realized Absorptive Capacity \\
& $(\mathrm{RA})$ \\
\hline Constant & $0.453^{* * *}$ \\
& $(0.105)$ \\
\hline Social Capital (SC) & $0.942^{* * *}$ \\
& $(0.025)$ \\
\hline Firm Age (FA) & -0.007 \\
& $(0.005)$ \\
\hline Firm Size (FS) & 0.000 \\
& $(0.005)$ \\
\hline Adjusted $\mathrm{R}^{2}$ & 0.942 \\
& \\
\hline
\end{tabular}

$* * * p<0.01,{ }^{* *} p<0.05,{ }^{*} p<0.10,{ }^{a}$ Bata coefficients with standard

Table 4 presents the results of OLS regression analysis of the relationship between social capital and realized absorptive capacity. For Hypothesis 2 , the relationship between social capital and realized absorptive capacity is significant $(\mathrm{H} 2$ : $b 2=0.942, \mathrm{p}<0.01)$, thus, Hypothesis 2 is supported.

Table 5: Results of Regression Analysis.

\begin{tabular}{|l|c|}
\hline \multirow{2}{*}{$\begin{array}{l}\text { Independent } \\
\text { Variables }\end{array}$} & Dependent Variables \\
\cline { 2 - 2 } & Firm Innovation (FI) \\
\hline Constant & 0.123 \\
& $(0.108)$ \\
\hline Potential Absorptive Capacity & $0.801^{* * *}$ \\
(PA) & $(0.059)$ \\
\hline Realized Absorptive Capacity (RA) & $0.184^{* * *}$ \\
& $(0.059)$ \\
\hline Firm Age (FA) & 0.018 \\
& $(0.035)$ \\
\hline Firm Size (FS) & $-0.066^{* *}$ \\
& $(0.030)$ \\
\hline Adjusted $\mathrm{R}^{2}$ & 0.894 \\
& \\
\hline
\end{tabular}

$* * * p<0.01, * * p<0.05,{ }^{*} p<0.10,{ }^{a}$ Bata coefficients with standard

Table 5 presents the results of OLS regression analysis of the relationships between potential absorptive capacity, realized absorptive capacity, and firm innovation. Hypothesis 3, the relationship 
between potential absorptive capacity and firm innovation is significant (H3: b3 $=0.0 .801, p<0.01)$, thus, Hypothesis 3 is supported. Hypothesis 4 , the relationship between realized absorptive capacity and firm innovation is significant $(\mathrm{H} 4 \mathrm{:} \mathrm{b} 4=0.0 .184, \mathrm{p}<0.01)$, thus, Hypothesis 4 is supported.

\section{Conclusions}

The current study posits that the way in which a firm's external network and its internal network efficiency are comprised can be seen as crucial for the determination of the level of firm innovation. The diversity of networks of a firm can be an indicator of its external knowledge access. The findings of this study give evidence that suggests a firm's innovation is significantly increased by the potential absorptive capacity and realized absorptive capacity, which provides opportunities to gather an array of knowledge, to access novel information, and to create innovative outcomes. In addition to this, a firm's ability to gain, sustain, modify and implement contemporary knowledge from other firms is determined by their internal absorptive capacity (Cohen and Levinthal, 1990). Learning capabilities and ways in which to modify and implement external knowledge for its own use is a result of investing in such capabilities (Tsai, 2001). The social network of a firm allows it to attain new information through external knowledge (Nelson; 1982, Fleming; 2004), therefore both time and money will be saved for experiments on future innovation projects (Powell et al., 1996; Arora and Gambardella, 1994). In addition to this, it can be said that a firm's internal development capabilities empower it to assess, articulate, and incorporate the new external knowledge that it has gleaned from social networks (Powell et al., 1996; U. Lichtenthaler, 2009). Therefore, firms get increased value from their data and more knowledge can be gathered from their social network when they include a high level of absorptive capability. This suggests that firm absorptive capability and knowledge from external network correlate with one another.

More specifically, when firms seek out a wide range of knowledge, the absorptive capability of a firm impacts the level in which they can improve their innovation through the processes of seeking out, modifying, and utilizing said information (Kogut and Zander, 1992). Innovation is the contemporary unification of knowledge that firms already possess and the new knowledge that they have gathered (Arora and Gambardella, 1994; Fabrizio, 2009). When a firm employs a level of high absorptive capability, the pursuit of information, as a result is faster, and the implementation of a wide range of technological knowledge improves a firm's overall innovation (Laumann, 1978). In order to create innovation, research activities must involve the proper seeking out, understanding, and integrating of information. When considering the research on absorptive capability (Cohen and Levinthal, 1990), the knowledge that already exists within a firm increases its ability to pursue, comprehend, and exploit up to date information for problem solving exercises. Thus, firms with higher levels of absorptive capability can more easily gain new insights from networks with a mind to positively transform their innovation activities and obtain more efficient knowledge transfer (Lee, 2001).

This study has provided several important management insights regarding how social capital can become an important source for a firm's innovation. In addition, our research also implied that there is a non-linear relationship between social capital and firm innovation. Therefore, firms should find the optimal level of network diversity to reap the greatest benefits for innovation performance. However, this research also includes two overall limitations. First, since this research focused only exporting firms from leather products businesses, perhaps future research will examine how social capital can improve innovation in other industries such as the service industry. Second, subject to data availability, we were unable to observe how knowledge is transferred among individual firms and therefore we cannot provide direct evidence of such transfer processes and mechanisms. In this case, perhaps future studies can focus on these individual processes. 


\section{Acknowledgement}

I am also grateful to many thanks Mahasarakham Business School, Mahasarakham University, Thailand for support of this research presentation.

\section{References}

[1] Aaker, David A., Kumar, V. and Day, George S, (2001). New York: John Wiley and Sons; Marketing Research.

[2] A. Arora, A. Gambardella, (1994). Evaluating technological information and utilizing it: scientific knowledge, technological capability; and external linkages in biotechnology; Journal Economic Behaviors Organization; 24, 91-114.

[3] Adler, P.S., Kwon, S, (2002). Social capital: prospects for a new concept; Academy of Management Review; 27 (1), 17-40.

[4] Aldrich, H.E., Zimmer, C, (1986). Entrepreneurship through social networks. In: Sexton, D.L., Smilor, R.W. (Eds.); The art and science of entrepreneurship. Ballinger Publishing Company, Cambridge, MA; 3-23.

[5] Armstrong, J.S. and Overton, T.S, (1977). Estimating Non-response Bias in Mail Surveys; Journal of Marketing Research; (3) 396.

[6] B. Kogut, U. Zander, (1992). Knowledge of the firm, combinative capabilities, and the replication of technology; Organizational Science; (3), 383-397.

[7] Bourdieu, P, (1986). The Forms of Capital. In: Richardson, J.G. (Ed.), Handbook of Theory and Research for the Sociology of Education; Greenwood Press, Westport, CT.

[8] Burt, R.S, (1992). Structural Holes. Harvard University Press, Cambridge, MA Cardinal, Sorensen and Stuart, Tippins and Sohi, Tippins, M. J., \& Sohi, R. S. 2003, IT competency and firm performance: Is organizational learning a missing link?; Strategic Management Journal; 24, 745-761.

[9] C. Lee, K. Lee, J.M. Pennings, (2001). Internal capabilities, external networks, and performance: a study on technology-based ventures; Strategic Management Journal; 22, 612-640.

[10] Cohen, W.M. and Levinthal, D.A, (1990). Absorptive capacity: a new perspective on learning and innovation; Administrative Science Quarterly; 35,128-152.

[11] Coleman, J.S, (1990). Foundations of Social Theory. Harvard University Press, Cambridge, MA.Cummings, J and S Kiesler.2003, Coordination and success in multidisciplinary scientific collaborations; In Proc. 24th Int. Conf. Information Systems (ICIS); 296-303, Seattle, Washington, USA.

[12] Daghfous, A, (2004). Absorptive capacity and the implementation of knowledge intensive best practices. S.A.M; Advanced Management Journal; 69(2), 21-27.

[13] De Carolis, D.M., Litzky, B.E., Eddleston, K.A, (2009), Why networks enhance the progress of new venture creation: the influence of social capital and cognition; Entrepreneurship Theory \& Practice; 33(2), 527 545.

[14] E.O. Laumann. (1978), Community structure as interorganizational linkages; Annual Review Sociology. $4(1), 455-484$.

[15] Fukuyama, F. (1995), Trust: The Social Virtues and the Creation of Prosperity. Free Press, New York.

[16] G. Ahuja, (2002). Collaboration networks, structural holes, and innovation: a longitudinal Study: Administrative Science Quarterly: 45(3), 425-455.

[17] Gatignon et al., (2002). A structural approach to assessing innovation: Construct development of innovation locus, type, and characteristics; Management Science; 48(9), 1103-1122.

[18] G. Péron-Pinvidic , J. Van Wijk , D.J. Shillington , L. Gernigon, (2009). An introduction to the Tectonophysics Special Issue. Role of magmatism in continental lithosphere extension; Tectonophysics; 468, 1-5.

[19] Hair, H. F., Anderson, R. E., Tatham, R. L., and Black, W. C, (1998). Multivariate data analysis; London: Prentice Hall.

[20] H.D. Flap, (1991). Social capital in the reproduction of inequality, a review, Comp. Soc. Fam; Health Education; 20, 6179-6202.

[21] H.D. Flap, (1999). Creation and returns of social capital; Review Tocqueville; (20), 5-26.

[22] Henderson, RM and KB Clark, (1990). Architectural innovation: The reconfiguration ofexisting product technologies and the failure of established firms; Administrative Science Quarterly; 35(1), 9-30. 
[23] Indre Maurer and Mark Ebers, (2006). Dynamics of Social Capital and Their Performance Implications: Lessons from Biotechnology Start-Ups; Administrative Science Quarterly; 51(2), 262-292.

[24] Inkpen, A. C., and Tsang, E. W. K, (2005). Social capital, networks, and knowledge Transfer; Academy of Management Review; 30(1), 146-165.

[25] James C. Anderson and David W. Gerbing, (1988). Structural Equation Modeling in Practice: A Review and Recommended Two-Step Approach; Psychological Bulletin; (3)103, 411-423.

[26] K.R. Fabrizio, (2009). Absorptive capacity and the search for innovation; Res Policy; 38(2), 255-267.

[27] Lane, P. J., Koka, B. R., and Pathak, S, (2006). The Reification of Absorptive Capacity: A Critical Review and Rejuvenation of the Construct; Academy of Management Review; 31(4), 833-863.

[28] Lechner, C., Frankenberger, K., Floyd, S.W, (2010).Task contingencies in the curvilinear relationships between intergroup networks and initiative performance. Academy of Management Journal; 53(4), 865-889.

[29] L. Fleming, O. Sorenson, (2004). Science as a map in technological search; Strategic Management Journal; 25, 909-928.

[30] Liao, S-h, W-C Fei and C-C Chen, (2007). Knowledge sharing, absorptive capacity, and innovation capability: An empirical study of Taiwan's knowledge intensive industries; Journal of Information Science; 33(3), 340-359.

[31] Marshall, A, (1920). Principles of economics; An introductory volume. London; MacMillan.

[32] Maurer and Ebers, (2006). Dynamics of Social Capital and Their Performance Implications: Lessons from Biotechnology Start-Ups Indre Maurer and Mark Ebers; Administrative Science Quarterly; 51(2), 262292.

[33] M. Zollo, S. Winter, (2002). Deliberate learning and the evolution of dynamic capabilities; Organizational Science; (13), 339-352.

[34] Nahapiet, J and S Ghoshal, (1998). Social capital, intellectual capital, and the organizational advantage; Academy of Management Review; 23(2), 242-266.

[35] N. Lin, (2001). Social Capital: A Theory of Social Structure and Action; Cambridge University Press.

[36] Nunnally, J.C. and Bernstein, I.H, (1994). Psychometric Theory (3 ${ }^{\text {rd }}$ Edition); McGraw-Hill Series in Psychology; McGraw-Hill, Inc., New York: NY, 21, 451-468.

[37] Prajogo, D. I., and Ahmed, P. K, (2006). Relationships between innovation stimulus, innovation capacity, and innovation performance; R \& D Management; 36(5), 499-515.

[38] Putnam, R.D, (1995), Bowling alone: America's declining social capital; Journal of Democracy; 6, 65-78.

[39] R. Nelson, (1982). The role of knowledge in R\&D efficiency; Quality Journal Economic, 97, 453-470.

[40] Roberts, K. (2003), What strategic investments should you make during a recession to gain competitive advantage in the recovery?; Strategy \& Leadership; 31(4),31-39.

[41] Roberts, P. W., and Amit, R. (2003), The dynamics of innovative activity and competitive advantage: The case of Australian retail banking, 1981 to 1995; Organization Science; 14(2), 107-122.

[42] Selnes, F., and Sallis, J. (2003), Promoting relationship learning; Journal of Marketing; 67(3), 80-95.

[43] Schumpeter, JA, (1934). Theory of Economic Development. Cambridge; MA: Transaction Publishers.

[44] Sorensen and T.E. Stuart, (2000). Aging, Obsolescence and Organizational Innovation; Administrative Science Quarterly; 45, 81-112.

[45] Stock, G., Greis, N., and Fischer, W, (2001). Absorptive capacity and new product development; Journal of High Technology Management Research; 12, 77-91.

[46] Szymanski, DM, MW Kroff and LC Troy, (2007). Innovativeness and new product success: Insights from the cumulative evidence; Journal of the Academy of Marketing Science; 35(1), 35-52.

[47] Tsai, Y. C, (2006). Effect of social capital and absorptive capability on innovation in internet Marketing; International Journal of Management; 23(1), 157-166.

[48] Tsai, W., Ghoshal, S, (1998). Social capital and value creation: the role of intrafirm Networks; Academy of Management Journal; 41, 464-476.

[49] Utterback and Abernathy, (1975). U. Lichtenthaler, Absorptive capacity, environmental.

[50] U. Lichtenthaler, (2009). Absorptive capacity, environmental turbulence, and the complementarity of organizational learning processes; Academics Management Journal; 52(4), 822-846. 
[51] Welsch, H., Liao, J., and Stoica, M, (2001). Absorptive capacity and firm responsiveness:

An empirical investigation of growth-oriented firms; United States Association for Small Business and Entrepreneurship (USASBE) 2001 Conference: An Entrepreneurial

Odyssey; 7-10 February 2001, Orlando, Florida.

[52] Whittington, K.B., Owen-Smith, J., Powell, W.W, (2009). Networks, propinquity, and innovation in knowledge-intensive industries; Administrative Science Quarterly; 54, 90-122.

[53] W.M. Cohen, D.A. Levinthal, (1990). Absorptive capacity: a new perspective on learning and innovation; Administrative Science Quarterly; 35, (1), 128-152.

[54] W. Tsai, (2001). Knowledge transfer in intraorganizational networks: effects network position and absorptive capacity on business unit innovation and performance; Academics Management Journal; 44, 996-1004.

[55] Zahra, S.A. and George, G, (2002). Absorptive capacity: a review, reconceptualization, and extension; Academy of Management Review; 27,185-203.

[56] Zahra, S., and George, G, (2002). Absorptive capacity: A review, reconceptualization, and Extension; Academy of Management Review; 27(2), 185-203. 